some have the more recently described autosomal recessive form..$^{5}$ About one third of all albinos in Britain have tyrosinase negative oculocutaneous albinism, one third have the tyrosinase positive form, and most of the rest are equally divided between $\mathrm{X}$ linked and autosomal recessive ocular albinism. ${ }^{6}$

Many albino babies show delayed visual maturation, appearing blind or nearly blind in the first few months of life. Parents need to be reassured that vision will develop once other causes of "blindness" have been excluded.

Distinguishing between tyrosinase negative and tyrosinase positive oculocutaneous albinism is usually impossible in early childhood because the hairbulb test result is usually negative in the first two or three years of life irrespective of the form of albinism. By the time the test becomes useful the two forms can usually be distinguished clinically. Their distinction is important as the visual acuity achieved by each of these groups is different. Those who are tyrosinase negative seldom achieve a visual acuity better than $6 / 60$, and they usually have difficulty reading small print without the help of low vision aids. The children thus often find it difficult in normal schools even with additional tuition. In contrast, those with the tyrosinase positive form of oculocutaneous albinism usually achieve a visual acuity between $6 / 18$ and 6/36, and their near vision is good. Most can manage in normal schools.

Refractive errors are common in albinos and if appreciable should be corrected as early as is practicable. Albino children with myopia and astigmatism often dislike wearing spectacles as the visual benefit may be small. Those with hypermetropia benefit from correction, which improves their near vision. Albinos have abnormal visual pathways and lack the central mechanism for binocular single vision. ${ }^{7}$ Strabismus is therefore common and should be corrected if unsightly. An early operation may, however, lead to a consecutive strabismus because of the absence of binocular vision.

In addition to their visual problems albinos often have a verbal intelligence quotient much poorer than their score for performance. ${ }^{8}$ They thus tend to do well at school initially, but many then fail to progress with writing, which they tend to do slowly and with some letters written backwards. Albinos with these particular problems should be introduced to keyboard skills early in their education. Spooner, who probably suffered from tyrosinase negative oculocutaneous albinism, had difficulties that were more serious and more bizarre than those of most albinos; he probably had some additional reason for his lapses. ${ }^{1}$

Oculocutaneous albinos are troubled by photophobia and have to avoid burning their skin in the sun. Photophobia in older children can be helped by sun glasses, but young children often remove their glasses and have to be protected by a floppy hat and a hood over the pram. Contact lenses with an opaque scleral portion and painted irides have been tried but with limited success. In general, contact lenses are best reserved for teenagers and adults with appreciable refractive errors who do not wish to wear glasses. Protection of the skin is not usually a serious problem in Britain: clothing and ultraviolet barrier creams will usually prevent blistering and reddening.

Once a couple has had one child with oculocutaneous albinism they have a one in four chance of having another affected child. Prenatal diagnosis is now possible by examining fetal skin with electron microscopy'; this is probably not justified in Britain ${ }^{10}$ but may be in certain subtropical and tropical countries, where albinos are often social outcasts and have a high incidence of skin cancers. ${ }^{11}$ Parents of affected children need sympathetic counselling and need to be told not only of the genetic implications of the disorder but also of its effects throughout life. Parents often appreciate being able to discuss their problems with other parents of affected children, and the Albino Fellowship (16 Ronaldshaw Park, Ayr KA7 2TJ) fulfils this need for many.

BARRIE JAY

Professor of Clinical Ophthalmology,

Moorfields Eye Hospital,

City Road,

London ECIV 2PD

1 Potter JM. What was the matter with Dr Spooner? In: Fromkin VA, ed. Errors in linguistic performance. San Francisco: Academic Press, 1980:13-34.

2 Kugelman TP, Van Scott EJ. Tyrosinase activity in melanocytes of human albinos. $\mathcal{f}$ Invest Dermatol 1961;37:73-6.

3 Witkop CJ Jr, Quevedo WC Jr, Fitzpatrick TB. Albinism and other disorders of pigment metabolism. In: Stanbury JB, Wyngaarden JB, Fredrickson DS, eds. The metabolic basis of inherited disease, 5th ed. New York: McGraw Hill, 1983:301-46.

4 Nettleship E. On some hereditary diseases of the eye. Trans Ophthalmol Soc UK 1909;29:57-198. 5 O'Donnell FE Jr, King RA, Green RW, Witkop CJ Jr. Autosomal recessively inherited ocular albinism. Arch Ophthalmol 1978;96:1621-5.

6 Jay B, Witkop CJ, King RA. Albinism in England. Birth Defects 1982;18:319-25.

7 Coleman J, Sydnor CF, Wolbarsht ML, Bessler M. Abnormal visual pathways in human albinos studied with visually evoked potentials. Exp Neurol 1979;65:667-79.

8 Cole GF, Conn P, Jones RB, Wallace JA, Moore V. Cognitive function in albino children. Deo Med Child Neurol (in press).

9 Eady RAJ, Gunner DB, Garner A, Rodeck CH. Prenatal diagnosis of oculocutaneous albinism by electron microscopy of fetal skin. $\mathcal{f}$ Invest Dermatol 1983;80:210-2.

10 Taylor WOG. Prenatal diagnosis in albinism. Lancet 19871;i:1307-8.

11 Kinnear PE, Jay B, Witkop CJ Jr. Albinism. Surv Ophthalmol 1985;30:75-101.

\section{Angiotensin converting enzyme inhibitors in the elderly}

Angiotensin converting enzyme inhibitors have been introduced for treating hypertension and heart failure. ${ }^{12}$ Both conditions are common in older people, in whom existing treatments are not always well tolerated or optimally effective. Angiotensin converting enzyme inhibitors produce symptomatic and haemodynamic improvement in older patients with heart failure and may prolong the life of those most severely affected. ${ }^{3}$ Despite theoretical reasons why they should not, ${ }^{4}$ converting enzyme inhibitors do lower blood pressure in the elderly and are generally well tolerated..$^{5-8}$ Indeed, they produce greater improvements in the patients' quality of life than propranolol or methyldopa. ${ }^{9}$ The blood pressure response to angiotensin converting enzyme inhibitors is not predictably related to pretreatment plasma renin activity, ${ }^{10}$ and, unfortunately, in some elderly patients the blood pressure fall may be excessive and potentially dangerous.

Severe hypotension one to two hours after the first dose of captopril has been widely recognised. ${ }^{11}{ }^{12}$ After the first dose of enalapril hypotension may be delayed six to eight hours but is longer lasting (24-28 hours) and accompanied by renal, cardiac, or cerebral ischaemia. ${ }^{13}$ Several aggravating factors have been identified, but attempts to predict and prevent the hypotension have been disappointing. ${ }^{11}$ Hypotension is most often seen in patients also taking diuretics or in those who are hypovolaemic or hyponatraemic. ${ }^{11}$ Hypotension is more common in patients with cardiac failure $e^{14}$ but even in healthy elderly people a prominent fall in blood pressure may occur. ${ }^{15}$ As in the young, the hypotension is not usually accompanied by an increase in heart rate. ${ }^{15}$ Age related 
changes in renal elimination of enalapril may contribute to the fall in pressure. ${ }^{16}$

What can be done to minimise the chance of hypotension after the first dose, and if it occurs how should it be managed? In patients with heart failure who are taking diuretics it is rarely practicable to stop the diuretics. If they cannot be stopped then reducing the dose for 24-28 hours before giving the angiotensin converting enzyme inhibitor may be prudent. Patients at high risk should be closely supervised in hospital. Enalapril should be started in elderly patients at a dose of 2.5 mg or lower. Alternatively captopril $6.25 \mathrm{mg}$ may be preferred because of its shorter duration of effect.

If severe hypotension does occur patients should, if they can tolerate it, have their heads tilted down and their legs raised and should be given intravenous crystalloid while their central venous or right heart pressures are monitored. Atropine has been useful in some patients and may be worth trying if the heart rate is low..$^{14}$ Intravenous infusion of angiotensin II has been recommended, but this agent does not have a product licence in Britain and is not readily available. ${ }^{11}$ At present it cannot be recommended for routine use. There is no justification for using other intravenous pressor agents, catecholamines, or vasopressin.

Angiotensin converting enzyme inhibitors are an important new treatment for heart failure and hypertension in the elderly. Postmarketing surveillance has not highlighted important problems with these drugs, ${ }^{617}$ but if angiotensin converting enzyme inhibitors are to be more widely used in older patients practitioners must be aware of potential adverse effects, including renal damage and marrow suppression, which may be dose related. Both captopril and enalapril are eliminated by the kidney, and both age and cardiovascular disease can impair renal function, thus increasing the potential for adverse reactions.

Regius Professor of Materia Medica,

JOHN L REID

University of Glasgow,

Stobhill General Hospital,

Glasgow G2 3UW

1 Atkinson B, Robertson JIS. Captopril in the treatment of clinical hypertension and heart failure. Lancet 1979;ii:836-9.

2 Edwards CRW, Padfield PL. Angiotensin converting enzyme inhibitors: past, present and bright future. Lancet 1985; i:30-4.

3 Consensus Trial Study Group. Effects of enalapril on mortality in severe congestive heart failure: results of the North Scandinavian enalapril survival study. N Engl f Med 1987;316:1429-34.

4 Buhler FR. Age and cardiovascular response: determinants of an antihypertensive treatment concept primarily based on beta blockers and calcium entry blockers. Hypertension 1983;5: (Suppl 2):94-100.

5 Jenkins AC, Knill JR, Dreslinski GR. Captopril in the treatment of the elderly hypertensive patient. Arch Intern Med 1985;145:2029-31.

6 Forette F, Handfield-Jones R, Henry-Amar M, et al. Traitment de l'hypertension arterielle du sujet age par un inhibiteur de l'enzyme de conversion: enalapril. Presse Med 1985;14:2237-9.

7 Arr SM, Woollard ML, Fairhurst G, Pippen CAR, Rao SK, Cooper WD. Safety and efficacy of enalapril in essential hypertension in the elderly. Br $\mathcal{Y}$ Clin Pharmacol 1985;20:279-80P.

8 Woo J, Woo KS, Vallence-Owen J. Captopril versus hydrochlorothiazide/triamterene in mild to moderate hypertension in the elderly. Lancet 1986;ii:924.

9 Croog SH, Levine S, Testa MA, et al. The effects of antihypertensive drugs on the quality of life. N Engl f Med 1986;314:1657-64.

10 Man in't Veld AJ, Schicht IM, Derkx FHM, deBruyen JHB, Schalekamp MADH. Effects of an angiotensin converting enzyme inhibitor (captopril) on blood pressure in anephric subjects. $\mathrm{Br}$ Med $\mathcal{F}$ 1980;280:288-90.

11 Hodsman GP, Isles CG, Murray GD, Usherwood TP, Webb DJ, Robertson JIS. Factors related to first dose hypotensive effect of captopril: prediction and treatment. BrMed f 1983;286:832-4.

12 Cleland JF, Semple P, Hodsman P, Ball S, Ford T, Dargie H. Angiotensin II levels, haemodynamic and sympathoadrenal function after low dose captopril in heart failure. $A m \mathcal{J}$ Med 1984;77:880-6.

13 Webster J, Newnham DM, Petrie JC. Initial dose of enalapril in hypertension. Br Med $\mathcal{J}$ 1985;290:1-4.

14 Cleland JGF, Dargie HJ, McAlpine H, et al. Severe hypotension after first dose of enalapril in heart failure. BrMed f 1985;291:1309-11.

15 Ajayi AA, Hockings N, Reid JL. Age and the pharmacodynamics of angiotensin converting enzyme inhibitors, enalapril and enalaprilat. Br f Clin Pharmacol 1986;21:349-57.

16 Hockings N, Ajayi AA, Reid JL. Age and the pharmacokinetics of angiotensin converting enzyme inhibitors, enalapril and enalaprilat. Brf Clin Pharmacol 1986;21:341-8.

17 Cooper WD, Sheldon D, Brown P, Kimber GR, Isitt VL, Currie WJC. Post-marketing surveillance of enalapril: experience in 11710 hypertensive patients in general practice. $f R$ Coll Gen Pract 1987;37:346-9.

\section{Haemophilia, AIDS, and no fault compensation}

About 1200 British haemophiliacs have been infected with the human immunodeficiency virus (HIV) from the transfusion of factors VIII or IX. So far 60 have developed the acquired immune deficiency syndrome (AIDS), and 45 have died. The prognosis for the remainder is uncertain, but the signs are ominous. Denial of insurance and mortgage protection because of their infection means that most have no hope of providing for their widows and dependent children. Because of this the main thrust of the Haemophilia Society campaign launched this week is to ask the government to ensure that the family home is protected and that dependants receive a weekly non-means tested hardship allowance. The society also asks that haemophiliacs should be granted a disability premium to replace single payments and that this should be high enough to cover the costs of coping with problems related to $\mathrm{HIV}$ in addition to the underlying bleeding disorder.

In 1978 the Royal Commission on Civil Liability and Compensation for Personal Injury (the Pearson commission) put forward reasons why a no fault scheme for medical accidents should not be introduced in Britain. ${ }^{1}$ The commission admitted that some members thought that the arguments for and against such a scheme were finely balanced. A decade later reappraisal of the reasons for rejection shows that none apply to the small and finite number of haemophiliacs presently appealing for compensation from the government because of iatrogenic infection with the human immunodeficiency virus (HIV). On the contrary, one of the arguments for introducing a no fault scheme was that "blood products may be used which contain viruses the presence of which could not be foreseen."

The government response to earlier requests for help was that individual members should go to law in an attempt to establish negligence. It soon became clear, however, that legal opinion in both Britain and the United States was that claims for negligence against prescribing doctors, health authorities, or those companies that manufacture factors VIII or IX were unlikely to succeed. Haemophiliacs thus had to appeal to the government to be made a special case. The main difficulty that the Pearson commission saw with no fault compensation was establishing causation, "since the cause of many injuries could not be identified." In the case of the haemophiliacs causation is, of course, clear and unequivocal. The commission also thought there would be difficulty in distinguishing a medical accident from the natural progression of a disease or injury and from a foreseeable side effect of treatment; it worried, too, about adjudicating and administering a general no fault scheme. It envisaged prohibitive costs and difficulties in dealing with medical accidents occurring in private practice.

These difficulties should not arise with haemophiliacs as they are a readily defined group already known to haemophilia centre directors. Further, most are already receiving state benefits because of their primary disorder and therefore are also known to senior staff of the Department of Health and Social Security. The facts that haemophiliacs are well known and small in number must surely make administering a special scheme to help them straightforward and safe from abuse.

The new argument that the government has against the scheme is the difficulty in differentiating between haemo- 